\title{
Characterization of $\left(\mathrm{Mg}_{1.0} \mathrm{Zn}_{0.0}\right) \mathrm{TiO}_{3}+4 \mathrm{wt} \% \mathrm{Bi}_{2} \mathrm{O}_{3}$ Ceramics for Application as Resonator in Dielectric Resonator Oscillator Circuit
}

\author{
Lailatul Izza and Frida U. Ermawati
}

Physics Study Program, Department of Physics, FMIPA, Universitas Negeri Surabaya (UNESA), Surabaya 60231, Indonesia

\begin{tabular}{|c|c|}
\hline Article Info & ABSTRACT \\
\hline Article History: & \multirow{7}{*}{$\begin{array}{l}\mathrm{MgTiO}_{3} \text {-based ceramics have potential applications in telecommunications } \\
\text { systems at microwave frequencies, such as resonators in dielectric resonator } \\
\text { oscillator (DRO) circuits. This paper reports the results of } \\
\left.\left(\mathrm{Mg}_{1.0} \mathrm{Zn}_{0.0}\right) \mathrm{TiO}_{3}+4 \mathrm{wt} \% \mathrm{Bi}_{2} \mathrm{O}_{3} \text { (abbreviated } \mathrm{MZT} 0+4 \mathrm{wt} \% \mathrm{Bi}_{2} \mathrm{O}_{3}\right) \text { ceramic } \\
\text { fabrication to assess its potential to be used as a resonator in the } \mathrm{DRO} \text { circuit. } \\
\text { We characterized its structure, microstructure, and bulk density. The addition } \\
\text { of } 4 \mathrm{wt} \% \mathrm{Bi}_{2} \mathrm{O}_{3} \text { to } \mathrm{MZT0} \text { crystalline powder was carried out via ball-mill. The } \\
\text { milled powder was compacted using a die press to obtain pellets. All pellets } \\
\text { were sintered at } 1100^{\circ} \mathrm{C} \text { for } 4,6 \text {, and } 8 \mathrm{~h} \text {. Ceramic structures of the } 4 \text { and } 6 \mathrm{~h} \\
\text { holding time consists of } \mathrm{MgTiO}_{3} \text { phase }(94.33 \pm 2.68) \text { and }(95.34 \pm 1.95) \% \text { molar } \\
\text { respectively, while the rest phase was } \mathrm{TiO}_{2} \text {. The } 8 \text { - } \mathrm{h} \text { ceramic structure } \\
\text { comprises }(96.11 \pm 2.94) \% \text { molar } \mathrm{MgTiO}_{3} \text { accompanied by } \mathrm{Mg}_{2} \mathrm{TiO}_{5} \text { and } \mathrm{TiO}_{2} \text {. } \\
\text { The ceramics' microstructure consists of a cluster of grains with an average } \\
\text { diameter of } 1.32-2.24 \mu \mathrm{m} \text { and pores. Bulk density decreases with the increase } \\
\text { of sintering holding time. The } \mathrm{DRO} \text { characterization records a resonance signal } \\
\text { each at 5.207, 5.005, and } 5.121 \mathrm{GHz} \text { with power approaching } 0 \text { dBm, } \\
\text { suggesting that the } \mathrm{MZT} 0+4 \mathrm{wt} \% \mathrm{Bi}_{2} \mathrm{O}_{3} \text { ceramics can be used as a resonator in } \\
\text { the DRO circuit working in microwave frequencies, especially at } 5.0-5.2 \mathrm{GHz} \text {. }\end{array}$} \\
\hline $\begin{array}{l}\text { Accepted: February 09, } 2021 \\
\text { Revised: March 01, } 2021 \\
\text { Accepted: March 01, } 2021\end{array}$ & \\
\hline Keywords: & \\
\hline $\begin{array}{l}\mathrm{MZTO}+4 \text { wt } \% \mathrm{Bi}_{2} \mathrm{O}_{3} \\
\text { DRO resonance } \\
\text { structure } \\
\text { microstructure } \\
\text { density }\end{array}$ & \\
\hline density & \\
\hline Corresponding Author: & \\
\hline $\begin{array}{l}\text { Frida U. Ermawati } \\
\text { Email: frida.ermawati@unesa.ac.id }\end{array}$ & \\
\hline
\end{tabular}

\section{INTRODUCTION}

Currently, the telecommunications industry has been growing rapidly. To support this industry, dielectric materials are required to be used as electronic components. Wu (2013), Zhang (2012), Ermawati (2016), Rani (2016) and Zhang et al. (2018) reported that dielectric material ceramics based magnesium titanate $\left(\mathrm{MgTiO}_{3}\right)$ has the potential to be applied to satellite and cellular telecommunication systems operating at a microwave frequency 3-300 $\mathrm{GHz}$. One of the applications is as a dielectric resonator oscillator (DRO) material (Ermawati, 2020a; Ermawati, 2020b). Apart from the dielectric properties, one of the requirements for using $\left(\mathrm{Mg}_{1-\mathrm{x}} \mathrm{Zn}_{\mathrm{x}}\right) \mathrm{TiO}_{3}$ ceramics as a DRO material is to have dimensions that correspond to the sample holder on the DRO circuit (Ermawati, 2020a; Ermawati, 2020b). Skyworks (2017) and Olekede et al. (2017) reports that DRO is a microwave oscillator that uses ceramic dielectric material as an excellent frequency stabilizer (resonator).

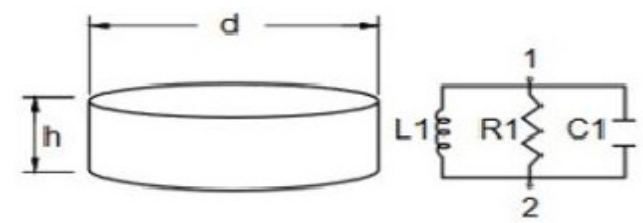

Figure 1. Cylindrical ceramic material used as a DRO type oscillator and its equivalence circuit (Skyworks, 2017; Ermawati et al. 2020a) 
In microwave communication systems, oscillators are energy sources. One of the oscillator types is the DRO type oscillator. An oscillator uses ceramic dielectric material as a frequencydetermining element to produce signals with excellent stability (Wibisono et al., 2010). Figure 1 provides a material dimension scheme used as a DRO-type oscillator and its equivalence circuit.

As seen in Figure 1, the DRO material is cylindrical with a thickness $h$ and diameter d, both in $\mathrm{mm}$ range. The equivalent DRO circuit consists of an inductor, resistor, and capacitor arranged in a parallel configuration. Ishida (2017) and Yamaguchi et al. (2018) reported that DRO could work in multiple modes. The mode is a transverse electric (TE) mode that propagates in a waveguide, either a rectangular- or cylindrical-waveguide made of a perfect conductor. According to Wenas et al. (2020), the propagating wave must have the smallest cut-off frequency (frequency limit), i.e., $\mathrm{TE}_{0.18}$, so that only one mode wave propagates. An isolated resonance frequency in $\mathrm{TE}_{0.1 \delta}$ mode $\left(f_{\mathrm{o}}\right)$ follows Equation 1 (Skyworks, 2017).

$$
f_{\mathrm{o}}(G H z)=\frac{8.553}{\sqrt{\varepsilon_{r}\left(\frac{\pi}{4} d^{2} h\right)^{1 / 3}}}
$$

where $d$ is the resonator diameter $(\mathrm{mm}), h$ is the thickness of the resonator material $(\mathrm{mm})$ and $\varepsilon_{r}$ is the resonator's dielectric constant. These $d$ and $h$ parameters are the same as in Figure 1.

A DRO circuit consists of four components: dielectric material that acts as a resonator, strip line, matching network, and feedback element (see Figure 2). The strip line is a waveguide circuit where electromagnetic waves propagate and produce a resonant frequency in the material being tested. A matching network is a series of impedance matching to ensure synchronization between input and output impedances for maximum power transfer. The feedback element is a feedback circuit block to ensure device stability for stable system performance. Figure 3 shows a block diagram of the resonant frequency measurement of the test ceramic in the DRO circuit. In Figure 3, the power supply functions as a voltage source, while the spectrum analyzer functions as a signal reader from the DRO in the form of a resonant signal at a certain frequency in the microwave region with a certain level (output power) in $\mathrm{dBm}$.

Fabrication of $\left(\mathrm{Mg}_{1-\mathrm{x}} \mathrm{Zn}_{\mathrm{x}}\right) \mathrm{TiO}_{3}$ ceramics has currently been reported, i.e., some of them are by Ermawati et al. (2016), Rettiningtyas et al. (2020), Rostianbudi et al. (2020), and Zendya et al. (2020). Ermawati et al. (2016) reported the ceramics' dielectric properties and their relation to the structure, microstructure and density. The rest publications reported the effect of $\mathrm{Bi}_{2} \mathrm{O}_{3}$ addition into the structure, microstructure and bulk density of $\left(\mathrm{Mg}_{1-\mathrm{x}} \mathrm{Zn}_{\mathrm{x}}\right) \mathrm{TiO}_{3}$ ceramics. No effort has been reported to study the ceramics' potential use as a resonator material in a DRO circuit operating in microwave frequencies.

Therefore, this paper is therefore intended to examine the potential use of $\left(\mathrm{Mg}_{1.0} \mathrm{Zn}_{0.0}\right) \mathrm{TiO}_{3}+4 \mathrm{wt} \% \mathrm{Bi}_{2} \mathrm{O}_{3}$ (hereinafter called $\mathrm{MZT} 0+4 \mathrm{wt} \% \mathrm{Bi}_{2} \mathrm{O}_{3}$ ) ceramics as a resonator in the DRO circuit in microwave frequencies and to characterize the structure, microstructure, and bulk density of the ceramics.

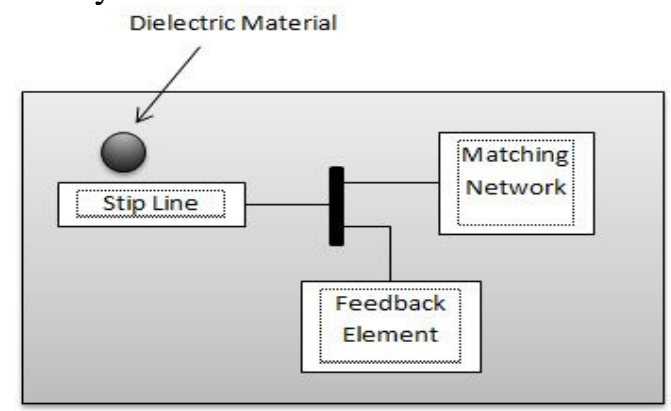

Figure 2. DRO circuit block diagram (Ermawati et.al, 2020a)

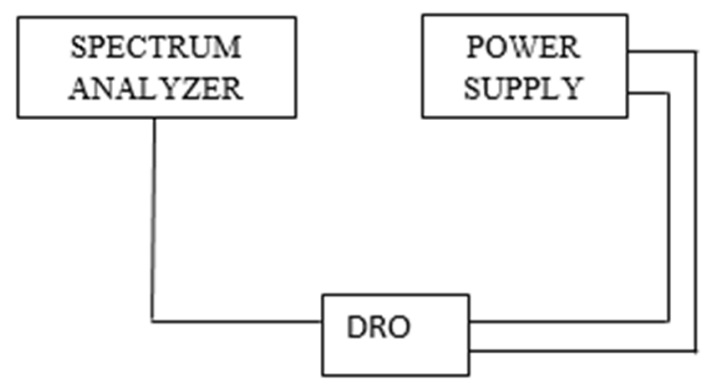

Figure 3. Block diagram of resonant frequency measurement of ceramic in a DRO circuit. The DRO block is the one shown in Figure 2 (Ermawati et al., 2020a) 


\section{METHOD}

\subsection{Ceramic Fabrication}

The ceramics fabrication was carried out by ball milling the MZT0 crystalline powder and $4 \%$ wt $\mathrm{Bi}_{2} \mathrm{O}_{3}$ powder (Merck) at $500 \mathrm{rpm}$ for $5 \mathrm{~h}$. The resulting powder was dried in the oven at $70^{\circ} \mathrm{C}$ for $3 \mathrm{~h}$. The dried powders were compacted using a hydraulic press and cylindrical die press with two different diameters, namely 10 and $5 \mathrm{~mm}$, pressed at $20 \mathrm{MPa}$ and $2.5 \mathrm{MPa}$ for 10 seconds to obtain pellets. The 10-mm pellets were intended for structure, microstructure, and bulk density characterization. While 5-mm pellets, as described in Figure 1, were for DRO resonance characterization. All pellets were sintered at $1100^{\circ} \mathrm{C}$ by varying the holding time of 4,6 , and $8 \mathrm{~h}$.

\subsection{Ceramic Characterisation}

The structure data of the ceramics were obtained from the XRD patterns measured using Bragg-Brentano Philips X'pert Diffractometer, $\mathrm{Cu}-\mathrm{K} \alpha$ radiation, $2 \theta=15-65^{\circ}$ and the detector step = $0.02 \%$ minute. The data were analysed qualitatively and quantitatively. Qualitative analysis was carried out using Match! software aiming to identify crystalline phases. Quantitative analysis was carried out by the Rietveld method using Rietica software (Hunter, 1998) to calculate the composition of the identified phases (Ermawati, 2018). Microstructure data from the fractured surface was examined using field emission scanning electron microscope (FESEM), FEI model Inspect F50. ImageJ software was used to measure the average diameter of grains and pores. Bulk density data was measured using Balance Mettler Toledo Type ME 403 E and Density Kit ME-DNY-43 using Archimedes method. The apparatus was integrated with Hyperterminal software to calculate the ceramic density using Equation (3)(Anugraha et al., 2014).

$$
\rho=\frac{m_{d}}{m_{w}+m_{a}} \rho_{a}
$$

where $\rho$ is ceramic density $\left(\mathrm{g} / \mathrm{cm}^{3}\right), m_{d}$ is ceramic dried mass $(\mathrm{g}), m_{a}$ is $\operatorname{Archimedes}$ mass $(\mathrm{g}), m_{w}$ is ceramic wet mass $(\mathrm{g}), \rho_{a}$ is aquadest density $\left(\mathrm{g} / \mathrm{cm}^{3)}\right.$. The DRO resonance frequency of the ceramic was measured using spectrum analyser (Keysight MXA Signal Analyser N9020A) operating in $\mathrm{TE}_{01 \delta}$ mode, 3-12 GHz, 9-12 Volt and 100-200 mA.

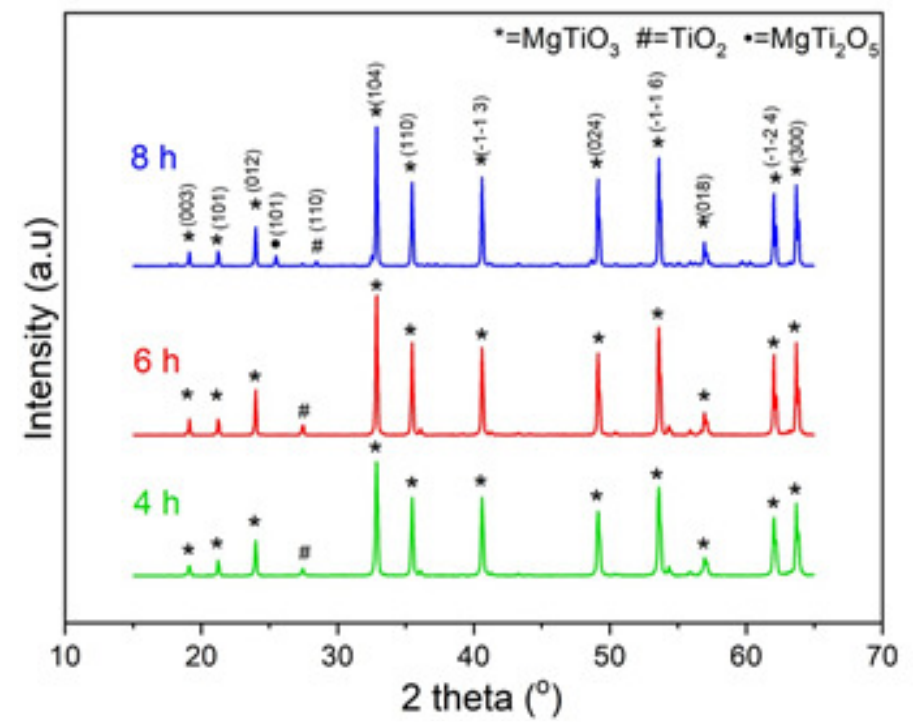

Figure 4. XRD patterns of MZT0+4wt $\% \mathrm{Bi}_{2} \mathrm{O}_{3}$ ceramics sintered at $1100^{\circ} \mathrm{C}$ for 4,6 and $8 \mathrm{~h}$

\section{RESULTS AND DISCUSSION}

\subsection{Characterization of Ceramic Structure}

\subsubsection{Qualitative Analysis}

Figure 4 shows the phase identification of the XRD patterns of MZT0+4wt $\% \mathrm{Bi}_{2} \mathrm{O}_{3}$ ceramics after the ceramics were sintered at $1100^{\circ} \mathrm{C}$ for 4,6 , and $8 \mathrm{~h}$ derived from Match! In Figure 4, the peaks 
with (*) symbol belong to the $\mathrm{MgTiO}_{3}$ phase (PDF 06-0494), the peaks with the symbol (\#) represent $\mathrm{TiO}_{2}$ Rutile (PDF 21-2176) phase, and the (•) symbol are $\mathrm{MgTi}_{2} \mathrm{O}_{5}$ (PDF 35-0792) peaks. As seen in Figure 4, the peaks with the (*) symbol belong to the desired $\mathrm{MgTiO}_{3}$ as the main phase and leaves $\mathrm{TiO}_{2}$ Rutile as the impurity. The extra minor $\mathrm{MgTi}_{2} \mathrm{O}_{5}$ phase was detected at $8 \mathrm{~h}$. The presence of the $\mathrm{MgTi}_{2} \mathrm{O}_{5}$ phase was likely derived from the reaction between $\mathrm{MgTiO}_{3}+\mathrm{TiO}_{2} \rightarrow \mathrm{MgTi}_{2} \mathrm{O}_{5}$ (Adikaning et al. 2016) due to prolonging sintering-holding time from 4, 6 to $8 \mathrm{~h}$. Rettiningtyas et al. (2020) who fabricated $\left(\mathrm{Mg}_{0.8} \mathrm{Zn}_{0.2}\right) \mathrm{TiO}_{3}+2 \mathrm{wt} \% \mathrm{Bi}_{2} \mathrm{O}_{3}$ ceramics and sintered the ceramics at $1100^{\circ} \mathrm{C}$ for $8 \mathrm{~h}$ also produced the main phases of $\mathrm{MgTiO}_{3}$ accompanied by minor $\mathrm{MgTi}_{2} \mathrm{O}_{5}$ and $\mathrm{TiO}_{2}$ phases.

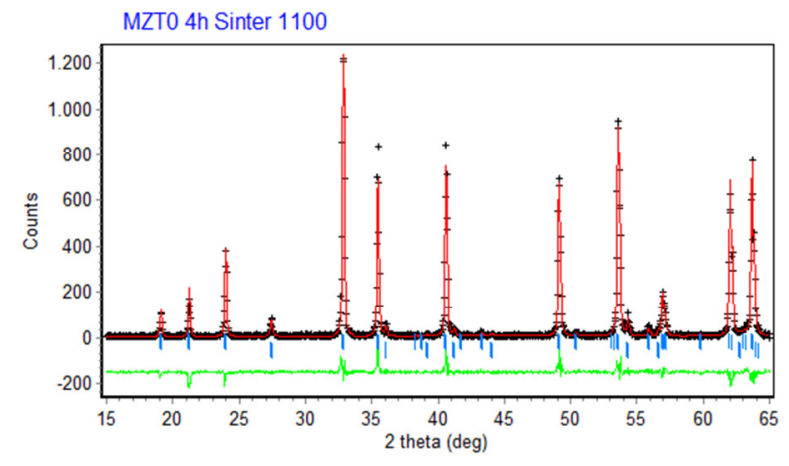

(a)

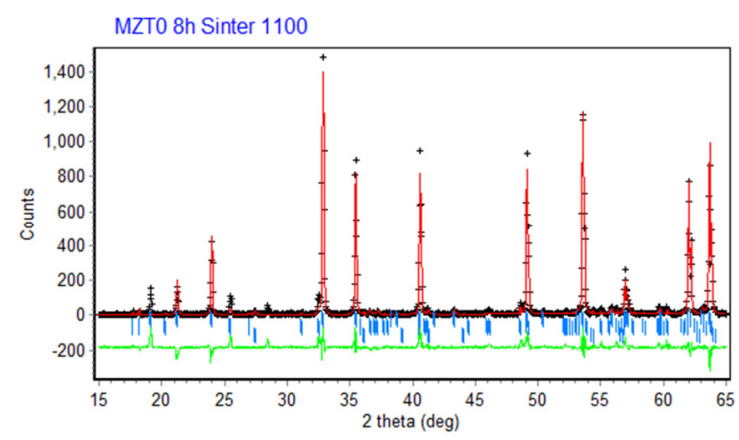

(c)

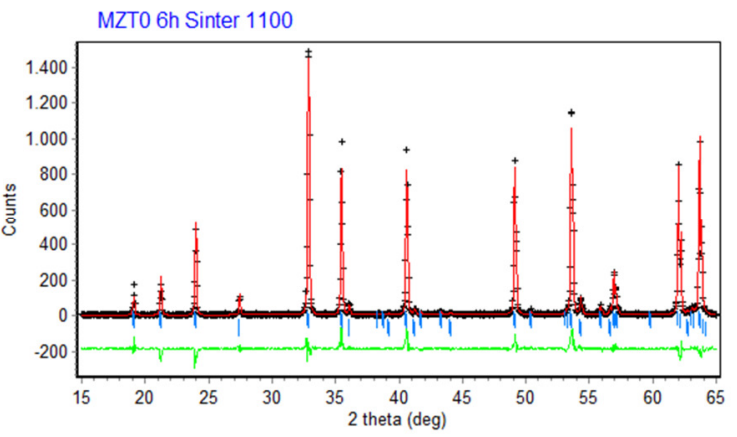

(b)

Figure 5. Rietveld refinement of the MZT0+4wt $\% \mathrm{Bi}_{2} \mathrm{O}_{3}$ pattern (a) $4 \mathrm{~h}$ Goodness of Fit $(\mathrm{GoF})=1.87, \mathrm{R}_{\mathrm{p}}=12.81, \mathrm{R}_{\mathrm{wp}}=20.86$ and $\mathrm{R}_{\mathrm{exp}}=15.27$, (b) $6 \mathrm{~h} \mathrm{GoF}=1.67, \mathrm{R}_{\mathrm{p}}=13.03, \mathrm{R}_{\mathrm{wp}}=19.83$ and $\mathrm{R}_{\text {exp }}=15.37$ (c) $8 \mathrm{~h} \mathrm{GoF}=3.22, \mathrm{R}_{\mathrm{p}}=17.88, \mathrm{R}_{\mathrm{wp}}=27.92$ and $R_{\exp }=15.56$

\subsubsection{Quantitative Analysis}

Figures 5a-c depicts the Rietveld refinement of the three XRD patterns in Figure 4. In Figures $5 \mathrm{a}-\mathrm{c}$, the (+) symbol is the experimental pattern, the red line is the calculated (model) pattern, the green line is the difference between the intensity of the experiment pattern and that of the model pattern, and the upright blue line indicates the Bragg peaks belonging to the identified phases, in this case, $\mathrm{MgTiO}_{3}, \mathrm{TiO}_{2}$, and $\mathrm{Mg}_{2} \mathrm{TiO}_{5}$ phases. The $\mathrm{GoF}, \mathrm{R}_{\mathrm{p}}, \mathrm{R}_{\mathrm{wp}}$, and $\mathrm{R}_{\text {exp }}$ data are figures of merit (FoM) of the refinement results. The output of the Rietveld refinement in Figures 5a-c, i.e., lattice parameters and unit cell volume of $\mathrm{MgTiO}_{3}$ phase as well as molar \% of the identified phases, are given in Figures 6-8.

Based on Figure 6, in general, it can be seen that the lattice parameters of $a=b$ and $c$ tend to increase with the sintering holding time. However, a slight decrease was observed on the $6 \mathrm{~h}$ holding time, i.e. from $(5.059 \pm 0.000) \AA$ for $4 \mathrm{~h},(5.059 \pm 0.000) \AA$ for $6 \mathrm{~h}$ and $(5.060 \pm 0,000) \AA$ for $8 \mathrm{~h}$ (the $\mathrm{a}=\mathrm{b}$ lattice); and $(13.915 \pm 0.000) \AA$ for $4 \mathrm{~h},(13.914 \pm 0.000) \AA$ for $6 \mathrm{~h}$ and $(13.916 \pm 0.000) \AA$ for $8 \mathrm{~h}$ (the c lattice). Rettiningtyas et al. (2020) reported the similar $\mathrm{a}=\mathrm{b}$ lattice parameters of $\mathrm{MgTiO}_{3}$ phase, i.e. $(5.060 \pm 0.000),(5.059 \pm 0.000)$ and $(5.060 \pm 0.000) \AA$. Meanwhile the c parameter was $(13.917 \pm$ $0.001),(13.914 \pm 0.001)$ and $(13.914 \pm 0.001) \AA$. Variation of the unit cell volume of the $\mathrm{MgTiO}_{3}$ phase in Figure 7 is similar to that of lattice parameters in Figure 6, i.e. (308.44 \pm 0.03$)$, (308.43 \pm 0.02$)$ and (308.56 \pm 0.02$) \AA^{3}$. This similarity is understandable because the volume of crystal unit cells is constructed by its lattice parameters. In Figure 8, the molar \% of the $\mathrm{MgTiO}_{3}$ phase also increases with 
the sintering holding time, i.e. $(94.33 \pm 2.68) \%$ for $4 \mathrm{~h},(95.34 \pm 1.95) \%$ for $6 \mathrm{~h}$ and $(96.11 \pm 2.94) \%$ for $8 \mathrm{~h}$; the rest $\%$ belongs to $\mathrm{TiO}_{2}$ and $\mathrm{MgTi}_{2} \mathrm{O}_{5}$ phases.

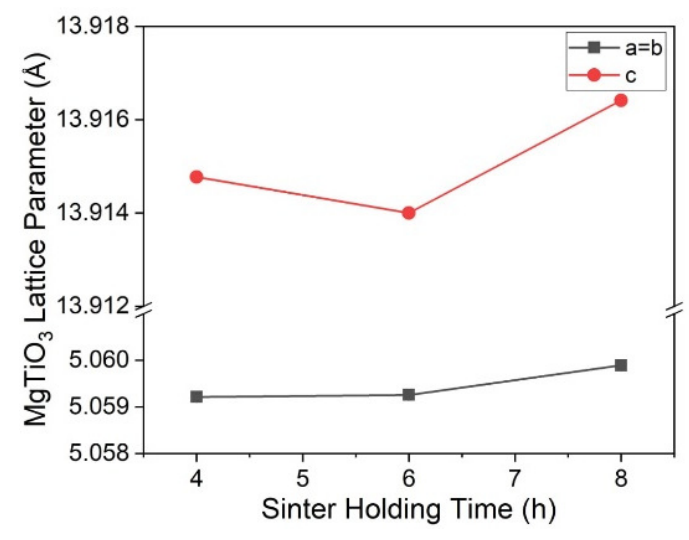

Figure 6. Lattice parameters of $\mathrm{MgTiO}_{3}$ phase in the three MZT0+4wt $\% \mathrm{Bi}_{2} \mathrm{O}_{3}$ ceramics. The data was the output of the refinement in Figure 5a-c.

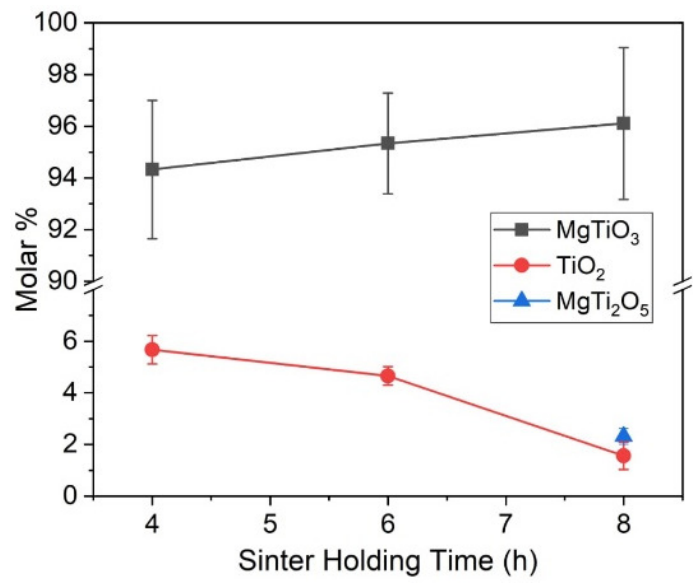

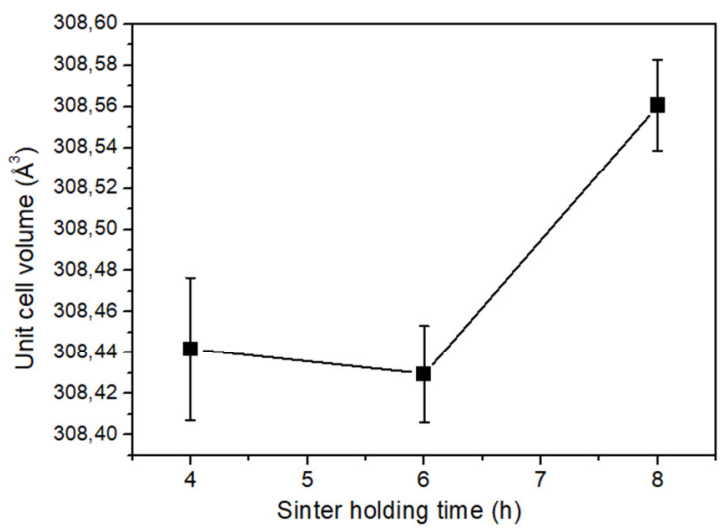

Figure 7. Unit cell volume of $\mathrm{MgTiO}_{3}$ phase in MZT0+4wt $\% \mathrm{Bi}_{2} \mathrm{O}_{3}$ ceramics. The data was the output of the refinement in Figure 5a-c

Figure 8. Molar $\%$ of the identified phases in MZT0+4wt $\% \mathrm{Bi}_{2} \mathrm{O}_{3}$ ceramics. The data was the output of the refinement in Figure 5a-c.

\subsection{Characterization of Ceramic Microstructures and Bulk Density}

Figures 9a-c show microstructures of the MZT0+4wt\% $\mathrm{Bi}_{2} \mathrm{O}_{3}$ ceramics due to 4,6 and $8 \mathrm{~h}$ of sintering holding time taken from a fractured surface, while Figure 10 depicts bulk density of the three ceramics. As seen in Figures 9a-c, there are three different colours on the microstructure: grey, white, and black. The grey and white ones are grains, while the black ones are pores. Every grain (in the blue circle in Figures 9a-c) is tiny, with an average diameter between 0.64-0.86 $\mu \mathrm{m}$. Most of the grains are sticking to each other (inside the red circle) with various sizes, namely 1.32-2.24 $\mu \mathrm{m}$.

In Figures 9a-c, the pores are also seen clearly on the ceramic surface with $4 \mathrm{~h}$ holding time; the average diameter of pores reduced on the ceramics with 6 and $8 \mathrm{~h}$. However, the cause of the grain sticking cannot be explained yet, considering that the addition of $\mathrm{Bi}_{2} \mathrm{O}_{3}$ powder as a liquid additive agent to the powder was intended to accelerate the compacting process of the powder into a ceramic (Wu, 2013 and Rettiningtyas, et.al 2020). On the way to reach the sintered temperature (in this case was $\left.1100^{\circ} \mathrm{C}\right)$ and when the melting temperature of $\mathrm{Bi}_{2} \mathrm{O}_{3}\left(\sim 860^{\circ} \mathrm{C}\right)$ was reached; the $\mathrm{Bi}_{2} \mathrm{O}_{3}$ will turn into a liquid phase. The liquid phase then fills the pores between the grains, i.e. the areas with low potential, to compact the grains (Ermawati, 2017). In this way, the compaction process of MZT0+4wt $\% \mathrm{Bi}_{2} \mathrm{O}_{3}$ ceramics was expected to occur at a lower sintering temperature compared to the compaction process of the ceramics without $\mathrm{Bi}_{2} \mathrm{O}_{3}$ addition (Ermawati, 2020c). The data in Figures 9ac shows that the variation in sintering holding time does not significantly affect the ceramic microstructures. 


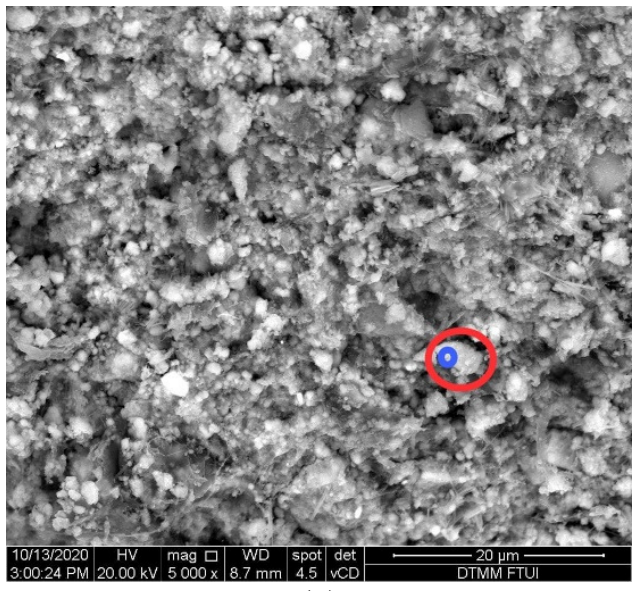

(a)

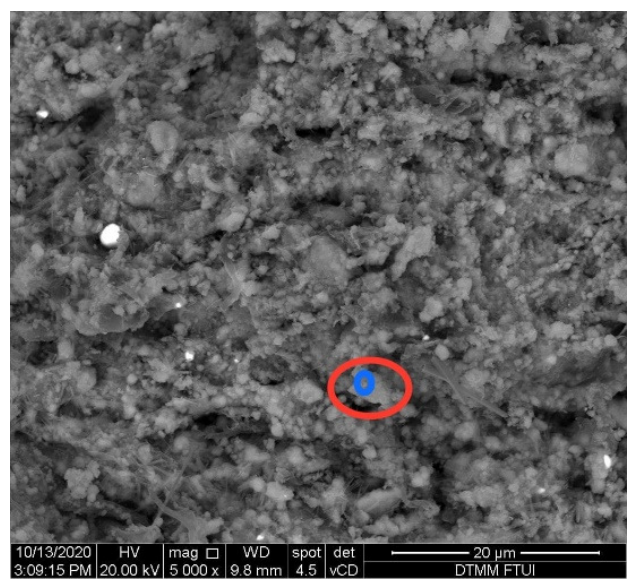

(c)

Figure 9. Microstructure of $\mathrm{MZT} 0+4 \mathrm{wt} \% \quad \mathrm{Bi}_{2} \mathrm{O}_{3}$

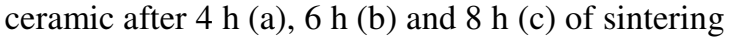
holding time.

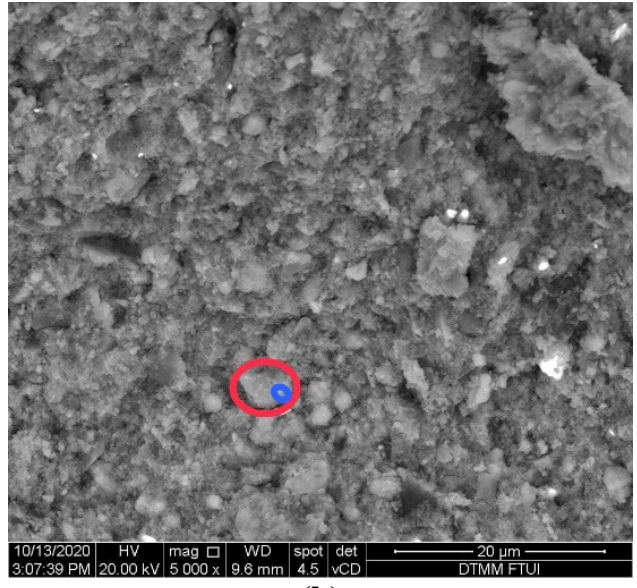

(b)

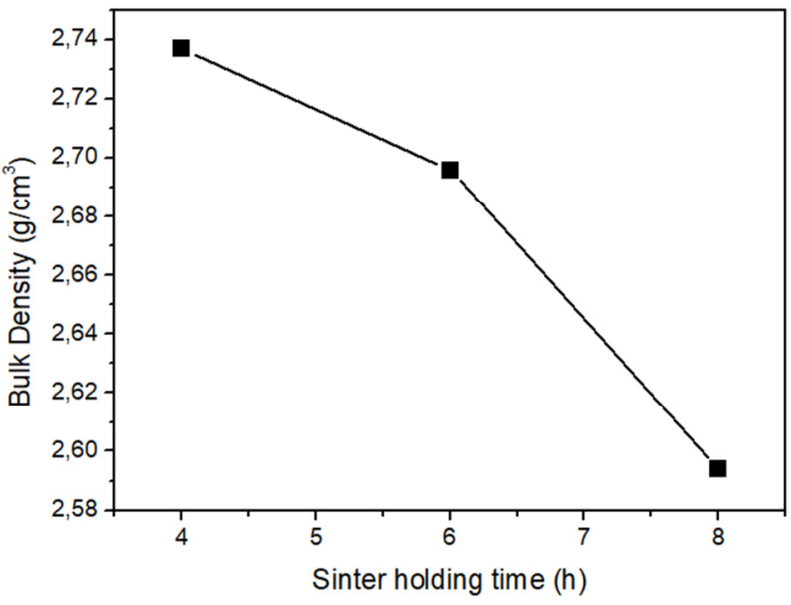

Figure 10. Bulk density of the three $\mathrm{MZT} 0+4 \mathrm{wt} \% \mathrm{Bi}_{2} \mathrm{O}_{3}$

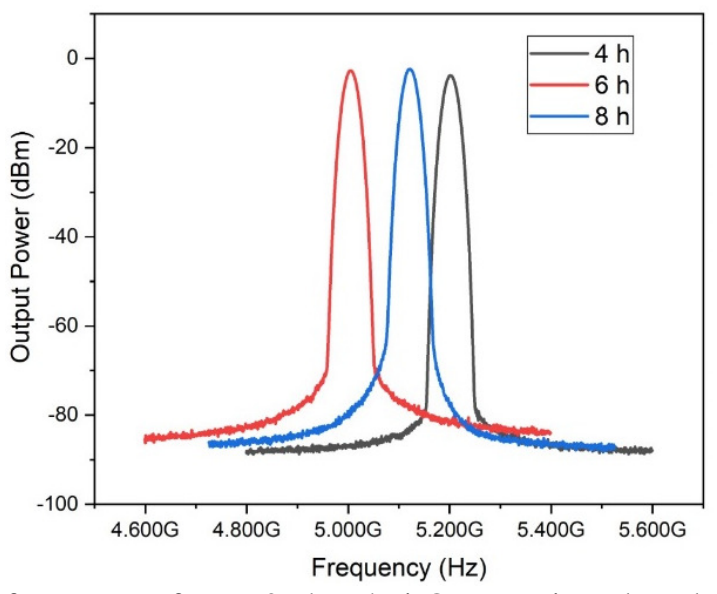

Figure 11. The resonance frequency of $\mathrm{MZT} 0+4 \mathrm{wt} \% \mathrm{Bi}_{2} \mathrm{O}_{3}$ ceramics when the ceramics acting as a DRO material in the DRO circuit

As seen in Figure 10, the density decreases with sintering holding time, i.e. 2.737; 2.696 and $2.594 \mathrm{~cm} / \mathrm{gm}^{3}$. This data suggests that in addition to the pores' presence in Figures 9a-c, other factors 
Izza and Ermawati: Characterization of $\left(\mathrm{Mg}_{1.0} \mathrm{Zn}_{0.0}\right) \mathrm{TiO}_{3}+4 \mathrm{wt} \% \mathrm{Bi}_{2} \mathrm{O}_{3}$ Ceramics for Application as Resonator

cannot be explained in this study but effect of the decrease in the density of ceramics in Figure 10, including the longer sintering holding time. Johan \& Ramlan (2008) reported the decrease in density in $\mathrm{Na}-\beta$ "'- $\mathrm{Al}_{2} \mathrm{O}_{3}$ ceramics was due to increased sintering holding time of up to $8 \mathrm{~h}$. It was reported that the pores were bigger due to the gases needed to strengthen the atomic bonds was burnt or evaporated so that the density reduced. This argument, however, cannot be clarified for the case of the MZT0+4wt $\% \mathrm{Bi}_{2} \mathrm{O}_{3}$ ceramics.

\subsection{Characterization of Ceramic as a Resonator in DRO Circuit}

Figure 11 showed the signals of resonance frequency and the output power as the response of MZT0+4wt\% $\mathrm{Bi}_{2} \mathrm{O}_{3}$ ceramics when the ceramic was mounted on the DRO circuit as a DRO resonator material. In Figure 11, the resonance frequency signals were recorded at the positions of 5.207; 5.005 and $5.121 \mathrm{GHz}$ for the ceramics with 4,6 and $8 \mathrm{~h}$ of holding time, each with the output power at $3.827,-2.749$ and $-2.366 \mathrm{dBm}$. As has been explained in the Introduction section, the frequency region for a ceramic dielectric material required for applications in satellite and cellular telecommunication systems is in 3-300 GHz; therefore, the three DRO resonance signals' performance in Figure 11 are equally good. An ideal DRO resonant signal generated from a ceramic dielectric material is sharp with a narrow frequency width. However, considering that it is challenging to fabricate the ideal ceramic, which contains only the expected phase, without any defects, either in the form of pores or other unexpected phases, then the ideal resonance DRO signal is also challenging obtain. These data confirmed that the MZT0+4wt $\% \mathrm{Bi}_{2} \mathrm{O}_{3}$ ceramics could be applied as a resonator on the DRO circuit operating in the microwave region, especially at 5.0-5.2 GHz with the output power approaches to zero. The increase in sintering holding time tends to slightly shift the resonance frequency signals' position towards the lower position.

\section{CONCLUSION}

The work to fabricate the MZT0+4wt\% $\mathrm{Bi}_{2} \mathrm{O}_{3}$ ceramics and characterize the structures, microstructures, and bulk densities and examine the potential use as a resonator in the DRO circuit has been completed. The result of ceramic fabrication shows that the expected $\mathrm{MgTiO}_{3}$ phase was identified as the main phase. Variation of sintering holding time did not alter the structure and microstructure but reduced the ceramics' density. The DRO characterization confirmed the ceramics' usefulness as a DRO resonator in microwave regions, particularly at 5.0-5.2 GHz.

\section{REFERENCES}

Adikaning, Sefrilita R. \& Suasmoro, D. (2016). $\mathrm{Mg}_{0,8} \mathrm{Zn}_{0,2} \mathrm{TiO}_{3}$ Ceramics Synthesize as Dielectric Material by Attritor Mill Mixing Methods. Institut Teknologi Sepuluh Nopember (ITS)

Anugraha, V. G., \& Widyastuti. (2014). Pengaruh Komposisi Sn dan Variasi Tekanan Kompaksi terhadap Densitas dan Kekerasan Komposit Cu-Sn untuk Aplikasi Proyektil Peluru Frangible dengan Metode Metalurgi Serbuk. Jurnal Teknik POMITS, 3(1), pp. 2

Ermawati, F. U. (2017). Fisika Bahan Keramik. Buku Ajar Mahasiswa, Surabaya: UNESA UniPress Surabaya. Sertifikat Hak Cipta RI, No. Pencatatan 000104991 Tahun 2018

Ermawati, F. U. (2018). Difraksi Sinar-X: Teori dan Analisis Data Eksperimen. Buku Ajar Mahasiswa, Surabaya: UNESA UniPress Surabaya.

Ermawati, F. U., Pratapa S., Suasmoro S., Hübert T., \& Banach, U. (2016). Preparation and Structural Study of $\mathrm{Mg}_{1-\mathrm{x}} \mathrm{Zn}_{\mathrm{x}} \mathrm{TiO}_{3}$ Ceramics and Their Dielectric Properties from $1 \mathrm{~Hz}$ to $7.7 \mathrm{GHz}$. Journal of Materials Science: Materials in Electronics, 27(7), 6637-45.

Ermawati, F. U., Wahyu Y., Kristiantoro T., \& Dedi. (2020a). Blok Diagram Sirkuit DRO dan Blok Diagram Pengukuran Frekuensi Respon dan Daya Luaran DRO Pada C-Band untuk Keramik Dielektrik $\left(\mathrm{Mg}_{1-x} \mathrm{Zn}_{x}\right) \mathrm{TiO}_{3}$. Modul. Sertifikat Hak Cipta RI, No. Pencatatan 000203671 Tahun 2020

Ermawati, F. U., Wahyu Y., Kristiantoro T., \& Dedi. (2020b) "Metode Fabrikasi Keramik Dielektrik $\left(\mathrm{Mg}_{1-x} \mathrm{Zn}_{x}\right) \mathrm{TiO}_{3}$ sebagai Dielektrik Resonator Osilator yang bekerja pada Pita C". Paten Indonesia. No. Permohonan P00202006498, 04 Sept. 2020. 
Ermawati, F. U. (2020c). The Response of $\left(\mathrm{Mg}_{0,6} \mathrm{Zn}_{0,4}\right) \mathrm{TiO}_{3}$ Ceramic System as A Dielectric Resonator Oscillator at C-Band. Makalah: Seminar Nasional Fisika 2020, Jurusan Fisika, FMIPA Universitas Negeri Surabaya.

Hunter, B. (1998). Rietica: A Visual Rietvield Program. Newsletter for International Union of Crystallography. Commission on Powder Diffraction 21.

Ishida E., Miura K., Shoji Y., Yokoi H., Mizumoto T., Nishiyama N., \& Arai S. (2017). Amorphus-Si Waveguide on a Garnet Magneto-Optical Isolator with a TE Mode Nonreciprocal Phase Shift. Optical Express, 25 (1), 452-462.

Johan, A. \& Ramlan. (2008). Karakterisasi Konduktivitas, Porositas dan Densitas Bahan Keramik Na$\beta$ "- $\mathrm{Al}_{2} \mathrm{O}_{3}$ dari Komposisi $\mathrm{Na}_{2} \mathrm{O} 13 \%$ dan $\mathrm{Al}_{2} \mathrm{O}_{3} 87 \%$ dengan Variasi Waktu Penahanan. Jurnal Sain, 11(3), 544-551.

Olokede, Seyi S., Zaki, Syazana B. B. M., Ain, Nor M. M. M. F., \& Ahmad, Z. A. (2017). Design of Negative Conductance Resonator Oscillator for X-Band Applications. Radioelectronics and Communications Systems, 60 (9), 413-422.

Rani, S. R. A. (2016). $\mathrm{Mg}_{0,8} \mathrm{Zn}_{0,2} \mathrm{TiO}_{3}$ Ceramics Synthesize as Dielectric Material by Attritor Mill Mixing Methods. Bachelor thesis, Department of Physics, Faculty of Mathematics and Natural Sciences. Institut Teknologi Sepuluh November: Surabaya

Rettiningtyas, N., \& Ermawati F. U. (2020). Sintesis dan Fabrikasi Keramik $\left(\mathrm{Mg}_{0,8} \mathrm{Zn}_{0,2}\right) \mathrm{TiO}_{3}+2 \mathrm{wt} \%$ $\mathrm{Bi}_{2} \mathrm{O}_{3}$ sebagai Bahan Dielektrik serta Karakterisasi Struktur dan Densitasnya Akibat Variasi Waktu Tahan Sinter. Jurnal Inovasi Fisika Indonesia (IFI), 09, 25-33.

Rostianbudi, F. Y., \& Ermawati, F. U. (2020). Fabrikasi Dan Karakterisasi Struktur Dan Densitas Keramik $\left(\mathrm{Mg}_{0,5} \mathrm{Zn}_{0,5}\right) \mathrm{TiO}_{3}+\mathrm{x}$ wt\% sebagai Kandidat Material Dielektrik. Jurnal Inovasi Fisika Indonesia (IFI), 09, 3-8.

Skyworks. (2017). Properties, Test Methods, and Mounting of Dielectric Resonators: 2. https://cmsitecore.skyworksinc.com/-/media/SkyWorks/Documents/Products/2501-

2600/Properties_and_Mounting_of_Dielectric_Resonators_202803B.pdf. Retrieved on February 11, 2020.

Wenas, D. R. (2020). Analisis Pandu Gelombang Menggunakan Bragg Reflector sebagai Cladding. Jurnal Fista (Fisika dan Terapannya). 1(1) pp. 7

Wibisono, G. \& Firmansyah, T. (2010). Perancangan Dielectric Resonator Oscillator Untuk Mobile Wimax Pada Frekuensi 2,3 Ghz Dengan Penambahan Coupling 2/4. in IEEE Region 10 Conference on TENCON (IEEE) July 2015: 140-44.

Wu, Shunhua, Wei, Xuesong, Wang, Xiaoyong, Yang, Hongxing, \& ShunqiGao. (2013). Effect $\mathrm{Bi}_{2} \mathrm{O}_{3}$ additive on the microstructure and dielectric properties of $\mathrm{BaTiO}_{3}$-based ceramics sintered. Journal of Materials Science and Technology, 26(5), 472-476.

Yamaguchi, R., Shoji Y., \& Mizumoto, T. (2018). Low-loss Waveguide Optical Isolator with Taperede Mode Converter and Magneto-Optical Phase Shifter for TE Mode Input. Optical Express 26(16), pp. 21271-21278

Zendya, L., \& Ermawati F. U. 2020. Pengaruh Variasi Tekanan Kompaksi Terhadap Mikrostruktur dan Densitas Keramik $\left(\mathrm{Mg}_{0,9} \mathrm{Zn}_{0,1}\right) \mathrm{TiO}_{3}+2 \%$ wt $\mathrm{Bi}_{2} \mathrm{O}_{3}$ Hasil Sintesis Menggunakan Metode Pencampuran Larutan. Jurnal Inovasi Fisika Indonesia (IFI), 09, 145-51.

Zhang, M., Lingxia, L, Wangsuo, X. \& Qingwei, L. (2012). Structure and Properties Analysis for $\mathrm{MgTiO}_{3}$ and $\left(\mathrm{Mg}_{0.97} \mathrm{M}_{0.03}\right) \mathrm{TiO}_{3}(\mathrm{M}=\mathrm{Ni}, \mathrm{Zn}$, Co and $\mathrm{Mn})$ Microwave Dielectric Materials. Journal of Alloys and Compounds, 537, 76-79.

Zhang, J., Zhenxing, Y., Yu, L., \& Longtu, L. (2018). $\mathrm{MgTiO}_{3} / \mathrm{TiO}_{2} / \mathrm{MgTiO}_{3}$ : An Ultrahigh-Q and Temperature-Stable Microwave Dielectric Ceramic through Cofired Trilayer Architecture. Ceramics International, 44(17), 21000-3. 